\title{
Are Tax-Free Wine Prices Attractive for Consumers? Empirical Evidence from Norway
}

\author{
Jan Bentzen ${ }^{1}$, \& Valdemar Smith ${ }^{1}$ \\ ${ }^{1}$ Department of Economics and Business Economics, Aarhus University, Denmark \\ Correspondence: Jan Bentzen, Department of Economics and Business Economics, Fuglesangs Alle 4, 8210 \\ Aarhus, Denmark.
}

Received: April 17, 2020

doi:10.5539/ibr.v13n7p130
Accepted: June 18, 2020

Online Published: June 23, 2020

URL: https://doi.org/10.5539/ibr.v13n7p130

\begin{abstract}
Wine is highly taxed in Norway, but there is a Norwegian island, Svalbard, with no taxes at all. For the purpose of comparing wine prices, with a focus on tax-free prices, we have collected a data set with identical wines from the two parts of Norway. At the retail level wines are only sold at state monopoly shops in mainland Norway and information from these allows a calculation of the before-tax prices in the country. The prices at the tax-free shop on Svalbard are significantly higher than the pre-tax prices and thus some monopoly price setting is taking place in the tax-free shop. Like in the present case duty-free shops often attract consumers with 'tax-free' prices, but some surplus is still extracted from the customers due to a monopoly behavior.
\end{abstract}

Keywords: wine taxes, tax-free shops, Vinmonopolet

\section{Introduction}

Consumers often associate tax-free prices with making a good deal, and thus people believe that prices on e.g. perfume, spirits, cameras, or even clothing are relatively cheap in duty-free areas such as international airports. However, there is an ongoing discussion as to whether tax-free prices at airports are indeed lower compared to prices in the retail sector, cf. Oslo Economics (2015). Travelers at airports may in fact be aware that the same goods can be purchased at competitive prices outside the tax-free airport shop. Still, these shops attract lots of travelers, and waiting time for the next flight departure is often used for shopping activities.

It is debatable whether tax-free prices at airports really are competitive or even comparable with the regular retail prices. Airport customers may differ in a lot of respects from the population in general, and the tax-free shopping takes place in a short time span whereas the normal, daily shopping is planned and done more routinely. Tax-free shopping may be an integrated and pleasurable part of traveling and hence the price elasticity may be low compared to the daily shopping. Nevertheless, the tax-free airport shopping may be done in order to buy some of the goods needed on e.g. a holiday or business trip and thereby it may be a fully rational choice.

The aim of this paper is to contribute to the discussion of whether tax-free wine prices really are free of taxes or some monopoly behavior is involved in the price setting. We look at the case of Norway where wine price data are available and suitable for an analysis of this kind. In Norway, mainland retail sales of wine and spirits take place from a state monopoly chain, Vinmonopolet ${ }^{1}$, which has 315 stores to cover all of the country. At the retail level Vinmonopolet has been given the sole license to sell beer, wine, and spirits with more than $4.75 \%$ of alcohol content. A general description and analysis of the market for alcoholic beverages in Norway can be found in Lai, Cavicchi, Rikertsen, Corsi and Casini (2013).

However, there is a large tax-free area in Norway, namely Svalbard, an archipelago one thousand kilometers away from the north coast of Norway. Svalbard is a group of islands with nearly 2700 inhabitants and includes a small Russian settlement on one of the islands. Thus, Svalbard is totally separated from the rest of Norway, and alcohol sales take place at a single shop called Nordpolet (in English: The North Pole). This shop has the sole license - like Vinmonopolet in mainland Norway - to sell alcohol, and therefore the market is an example of a virtual monopoly. Svalbard is visited by many tourists as a popular destination, and as noted in Timothy, Saarinen and Viken (2016) there is a considerable tax-free cross-border trade in the Nordic region, but this

1 www.vinmonopolet.no 
cannot be the main reason for selling tax-free wines at Svalbard. The travel to Svalbard is rather expensive and the special nature the obvious motivation for travel, and thus the relatively low tax-free prices of alcohol are a part of the general tax exemption of the island to make it more attractive to settle and cope with the otherwise high living costs. There is a somewhat similar case for an island belonging to Finland, Åland, which has been allowed tax-free sales of alcohol, Karlsson (1999). The effects have been increasing tourism and allowing the island inhabitants access to relatively cheap alcohol was part of an agreement if the island should continue as an EU member, and therefore deviating from the Svalbard case. As Svalbard is a tax-free zone, there is no viability of an airport duty-free shop as in other international airports, and tax-free shopping of alcohol takes place as mentioned in the shop Nordpolet in the city center.

With data for a large sample of wine prices from Nordpolet, collected in January 2018, we analyze the price setting of the Svalbard tax-free prices. The wines sold at Svalbard can also be found at Vinmonopolet, and thereby we can calculate and compare with price levels before tax and profits. This allows us to make an analysis of whether some kind of monopoly behavior exists and also whether tax-free prices really correspond to the before-tax prices.

\section{Data and Pricing Behavior}

Vinmonopolet at the mainland is a major player at the international wine markets as it imports most of the wines consumed at the Norwegian market, and as the state-owned monopoly shops constitute the only outlets for wine purchases - with the addition of restaurants. ${ }^{2}$ Wines can also be bought in tax-free shops in Norwegian airports at prices lower than found in the state monopoly shops, but this is conditional on making an international trip. The sales revenue from the airport tax-free shops is used for covering general costs of the Norwegian airports, cf. Flaten and Lilland (2017). There is a specific set of rules set by the Norwegian authorities on how to calculate the final consumer prices based on the import prices. The retail price calculation includes a wine tax, VAT, and profits to cover the operating costs. The rates and rules are fixed, which allows us to calculate the before tax and profits prices of the wines sold at Vinmonopolet.

There are several similarities between mainland Norway and Svalbard. From the supply side both retail markets have monopoly status and the majority of the inhabitants at Svalbard speak Norwegian and have the same cultural background. Therefore, these markets are relatively comparable with respect to a consumer analysis. Besides an analysis of wine price differences, we focus on whether pricing strategies are designed from a profit maximization point of view, i.e. whether the supply prices on Svalbard are economically optimal for creating the highest possible surplus. The case is that the surplus generated in the monopoly shop is solely used for various activities on Svalbard for the benefit of the local population and hereby creating an incentive for monopoly pricing.

The data used for the analyses was collected in January 2018. The wine prices are the actual prices found in the monopoly shop Nordpolet (obtained by a visit to the island), and the prices from Vinmonopolet in mainland Norway were downloaded in the same time period from the homepage. In order to evaluate the general price level, we include international prices on competitive markets from Wine Searcher in the data set (www.wine-searcher.com). Thus, the data collection strategy was to first collect all wine prices on Svalbard, hereafter find prices on identical wines at Vinmonopolet, and finally identify the same wines on competitive markets by using Wine Searcher. The consumption of alcohol at Svalbard is regulated according to a per-person quota system ${ }^{3}$. The monthly allowance is two bottles of spirits, 24 cans of beer, and a reasonable consumption of wine (no fixed quantity). Accordingly, it is reasonable to assume that the wine market functions like wine markets at other places.

The data in terms of numbers and average prices are shown in Table 1. The total number of different wines supplied by Nordpolet was 162, of which 106 were red wines (column 1) and 56 were white wines (column 3). The average price of the 106 red wines was NOK 152, and 87 of these brands are also found at Vinmonopolet with an average price of NOK 160.

\footnotetext{
${ }^{2}$ Private importers are allowed to sell wine through the Vinmonopolet sales outlets. Furthermore, importers who have been approved by a so-called procurement board can sell their wines directly to hotels and restaurants, see Lai et al. (2013).

${ }^{3}$ http://www.regjeringen.no/no/dep/asd/id165/
} 
Table 1. Average wine prices at Nordpolet, Svalbard, and the number of wines by country of origin (Prices in NOK; number of wines in parentheses)

\begin{tabular}{lllll}
\hline $\begin{array}{l}\text { Country } \\
\text { origin }\end{array}$ & of & $\begin{array}{l}\text { Red } \\
\text { Average price (Number of wines) }\end{array}$ & \multicolumn{2}{l}{$\begin{array}{l}\text { White } \\
\text { Average price (Number of wines) }\end{array}$} \\
\hline & Nordpolet & $\begin{array}{l}\text { Matching wines, } \\
\text { Vinmonopolet }\end{array}$ & $\begin{array}{l}\text { Nordpolet } \\
\text { Matching wines, } \\
\text { Vinmonopolet }\end{array}$ \\
Spain & $136(34)$ & $207(19)$ & $154(32)$ & $142(23)$ \\
Italy & $128(17)$ & $125(14)$ & $82(3)$ & $82(3)$ \\
Portugal & $186(36)$ & $183(31)$ & $108(4)$ & $113(3)$ \\
Germany & $84(5)$ & $71(3)$ & - & - \\
USA & - & - & $131(3)$ & - \\
Australia & $99(5)$ & $96(3)$ & $75(1)$ & $139(2)$ \\
New Zealand & $127(9)$ & $127(9)$ & $13(4)$ & $13586)$ \\
Chile & $102(4)$ & $113(1)$ & $101(3)$ & - \\
Argentina & $73(3)$ & $107(3)$ & - & - \\
South Africa & $88(2)$ & $73(3)$ & - & $132(40)$ \\
\hline All countries & $152(106)$ & $111(1)$ & $139(56)$ & - \\
\hline
\end{tabular}

Note. The prices from Nordpolet are tax-free prices in NOK $(1$ EURO $=9.33$ NOK). The number of brands in parentheses, e.g. 34 French red wines, and the number of matching wines with Vinmonopolet indicated in the next column, e.g. 19 wines with an average price of NOK 207. The prices for the matching wines are the Nordpolet prices (not prices at Vinmonopolet).

Wines from Italy and France dominate the group of red wines and account for more than $75 \%$ of the total supply of red wines. The supply of white wines is clearly in favor of French wines with 32 brands out of the total supply of 56 brands, i.e. nearly $60 \%$. The average price of the red wines is a little higher than for the white wines, i.e. NOK 152 versus NOK 139. Italian red wines are by far the most expensive with an average price equal to NOK 186, whereas red wines from Argentina are the cheapest with an average price of NOK 73. Looking at white wines, the French wines are the most expensive as the average price is NOK 154.

As mentioned above, the empirical strategy is to analyze prices on identical wines. From the 106 red wines on the shelves in Nordpolet the number of exactly identical red wines found at Vinmonopolets homepage was 87, and similarly 40 of the 56 white wines were also in the catalogue of Vinmonopolet. Column 2 and column 4 in Table 1 show the average prices for wines sold in Nordpolet where the same wines can be found at Vinmonopolet. The average price on French red wines that are also found at Vinmonopolet is notably higher than the average price of all French wines in Nordpolet, i.e. NOK 207 versus NOK 136. However, in general, the table shows very small differences in prices between matching wines and all wines sold on Svalbard. Therefore, it is reasonable to conclude that the matched data set is representable for the wine supply in the Svalbard shop.

\section{Price Comparisons and Correlations}

Figure 1 shows the prices for red and white wines from the tax-free Svalbard shop along with the corresponding prices for the identical wines from mainland Norway. It is easily seen that the tax-free prices on Svalbard are lower than the retail prices in Norway. Only three wines in the Svalbard shop are more expensive than the same wines from Vinmonopolet, and the mean price differences for the red and white wines are significant even at the $1 \%$ level. 


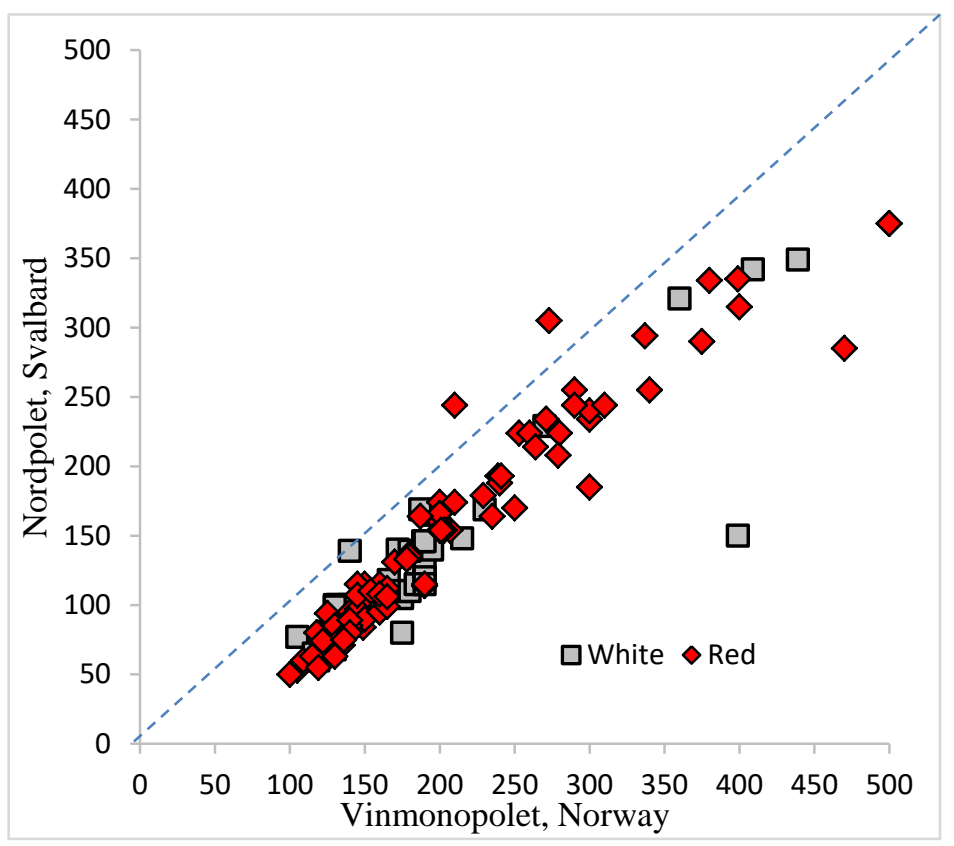

Figure 1. Market prices: Tax-free wine prices at Nordpolet, Svalbard, and retail prices from Vinmonopolet Note. Prices in NOK; 87 red and 40 white wines.

The prices to use for such a comparison is, however, an open question. Naturally, tax-free prices should be lower than the normal retail prices including taxes. Hence, a more precise analysis should use the same type of prices and therefore it seems reasonable to ask whether the tax-free prices are indeed comparable to the normal retail prices net of taxes. Figure 2 gives an answer to this question. Again, it is easily seen that there are systematic price differences between Svalbard and mainland Norway, but this time in favor of the latter. Thus, except for three wines, prices net of tax in Norway are lower than the tax-free prices on Svalbard.

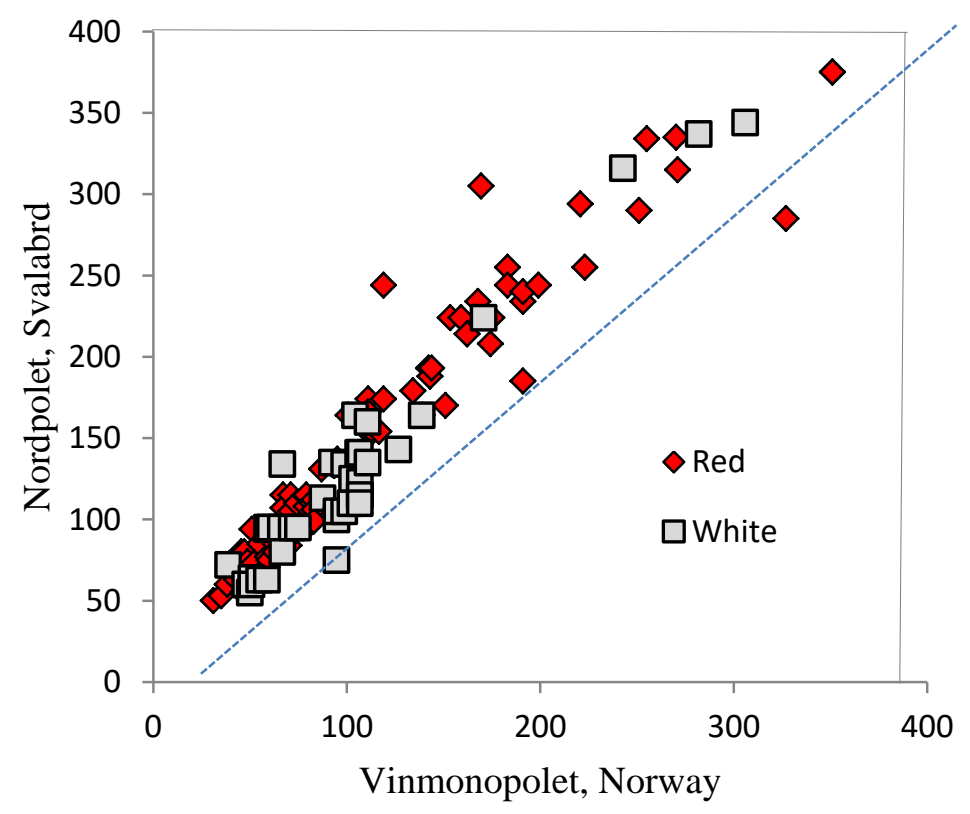

Figure 2. Tax-free wine prices, Nordpolet, Svalbard, and net of tax prices from Vinmonopolet

Note. Prices in NOK; 87 red and 40 white wines. The Svalbard tax-free prices have been reduced by the estimated extra transportation costs (NOK 5 per bottle). 
Overall, the mean price difference is NOK 29.9, for the red wines it is NOK 35.5, and for the white wines it is NOK 21.3. In all three cases the differences are significant at the $1 \%$ level. The figure also reveals a high degree of correlation between the prices for Norway and Svalbard and the Pearson coefficient of correlation is 0.89 for red wines and 0.96 for white wines. Thus, the tax-free prices at Nordpolet are significantly higher than the net of tax prices at Vinmonopolet calculated from price data for 127 exactly identical wines sold by both wine outlets.

This gives rise to the following hypothesis: Will a tax-free shop like Nordpolet act as a monopoly with a profit-maximizing price setting? The answer to this hypothesis will subsequently also reveal whether tax-free prices are corresponding to a net of tax price level and thereby not extracting a part of the consumer surplus. The hypothesis will be addressed by an empirical analysis of the wine price data from the duty-free Nordpolet compared to the wine price data from mainland Norway, as already exhibited in Figures 1 and 2. This question of monopoly pricing will be further analyzed in Section 4.

Table 2 shows the results of various regression analyses of the tax-free wine prices for Svalbard. Because the two markets are totally separated, substitution effects can be excluded and furthermore, if any causality exists, it is unidirectional, that is from the much larger mainland Norway to Svalbard. Controlling for country of origin, vintage, and red/white wines, it is clear that the price level on the mainland is significantly correlated with the Svalbard prices, i.e. the estimated coefficient is robust at around 0.82-0.85. The level effect is captured in the constant term with an estimated value between 0.9 and 0.98 , and the overall degree of explanation, 0.89 , is relatively high.

Table 2. Regression analysis of the wine prices from Nordpolet, Svalbard (prices in log values)

\begin{tabular}{llll}
\hline & $(1)$ & $(2)$ & $(3)$ \\
\hline Constant & $0.890^{*}$ & $0.841^{*}$ & $0.909^{*}$ \\
& $(0.122)$ & $(0.117)$ & $(0.129)$ \\
Price in Norway $(\log )$ & $0.866^{*}$ & $0.860^{*}$ & $0.836^{*}$ \\
& $(0.026)$ & $(0.025)$ & $(0.028)$ \\
Red=1, white=0 & & $0.106^{*}$ & $0.087^{*}$ \\
Overseas country =1, else & $(0.029)$ & $(0.031)$ \\
0 & & 0.038 \\
Vintage (years) & & $(0.035)$ \\
$\mathrm{R}^{2}$ & 0.89 & & $0.018^{* *}$ \\
Number of wines & 127 & 0.90 & $(0.007)$ \\
\hline
\end{tabular}

Note. Standard errors in parenthesis. * denotes $1 \%$ level of significance; ** 5\% level of significance.

\section{The Markup on Wine Prices - Do High Tax-Free Prices Make Sense?}

The previous section demonstrated that tax-free wine prices on Svalbard are significantly higher than the estimated prices net of taxes in Norway. Furthermore, the prices are highly correlated and therefore the markup on wine prices is expected to be systematically different between the two markets, unless operating costs are higher on Svalbard. The analysis below assumes that operating costs are identical.

The markup on wine prices at Vinmonopolet is regulated by law. It includes a fixed volume markup corresponding to NOK 8.9 per liter, a packing fee of NOK 1.57 per bottle, and an additional markup equal to $22 \%$ of the wholesale price. Hence, the wholesale price per bottle of wine including transportation and other variable costs can be calculated backwards from the retail price due to the centrally regulated price setting. The calculated before-tax prices for the wines sold at Vinmonopolet have been compared to international market prices collected from the Wine Searcher homepage for identical wines. The Norwegian before-tax prices seem to be rather close to market prices ${ }^{4}$ outside Norway, and thus Vinmonopolet and Nordpolet are facing the same price levels when importing wines.

Suppose that Nordpolet has the same wholesale purchase prices as Vinmonopolet. Then the absolute markup for a bottle of wine on Svalbard can be calculated from:

$$
\text { Markup }(\text { Svalbard })=\text { tax-free sales price }- \text { wholesale price }(\text { Vinmonopolet })-\text { extra transportation costs }
$$

\footnotetext{
${ }^{4}$ The Wine Searcher prices are retail prices before tax.
} 
Extra transportation costs to Svalbard by sea are set to NOK 1000 per cargo pallet consisting of 450 bottles according to information from Nordpolet given at the time of data collection on the island. In order to account for possible other costs, the extra transportation costs are assumed to be NOK 5 per bottle in the following computations.

This formula gives an estimated average markup per bottle of wine on Svalbard of about NOK 58. Naturally, the actual markup varies with the price segment to which the particular wines belong, and therefore the markup is calculated in percent of the wholesale price including extra costs. This results in an average percentage markup of $78 \%$ which is illustrated in Figure 3. The figure shows the percentage markup as a function of the wholesale price for wines sold at Svalbard. A partial Pearson coefficient of correlation has the value -0.31, which indicates the existence of a negative relationship. A similar behavior is also demonstrated in a recent thesis by Schrøder and Sveinung (2017) showing that the tax-free shops in Norwegian airports have a price setting for red wines 51\% above the before-tax prices, and $37 \%$ for white wines. This study calculates the before-tax prices like in the present study, cf. the explanation in relation to Figure 3. Thus, tax-free prices in airports at mainland Norway are set with a considerable markup, although smaller than found in the Svalbard case.

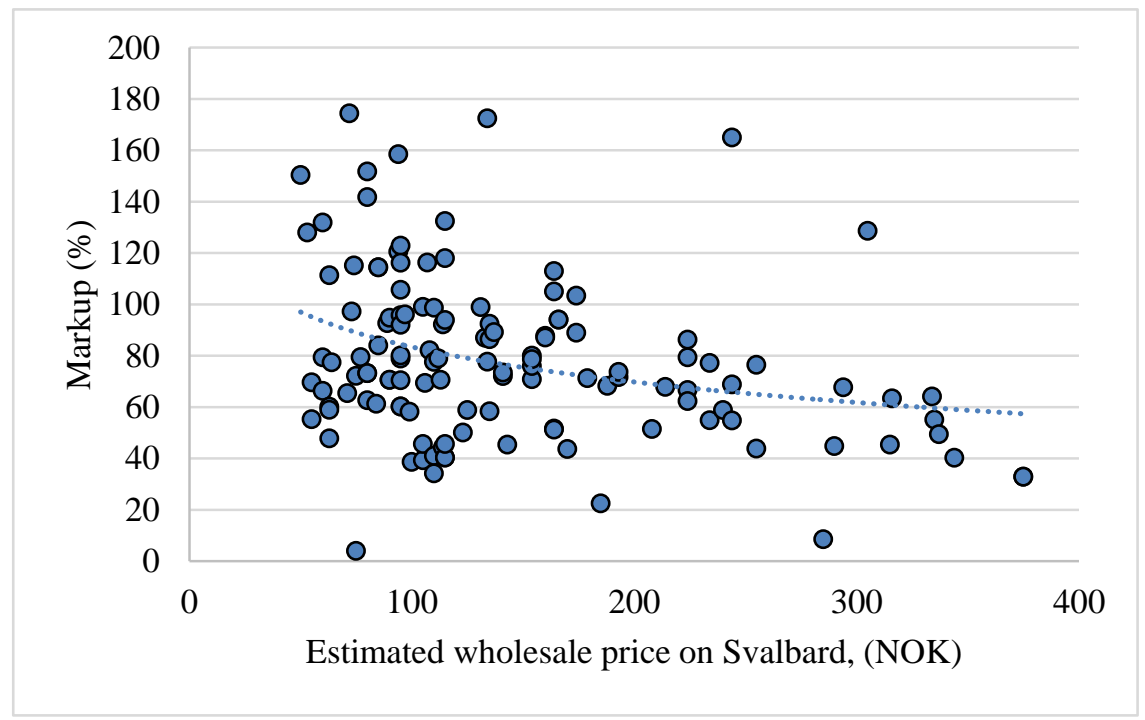

Figure 3. The markup at Svalbard in percentage of the wholesale price

Note. The Pearson coefficient of correlation is equal to -0.31 .

Noting that Nordpolet is the sole outlet for alcohol at Svalbard, the hypothesis is to test whether the high markup setting is consistent with monopoly pricing. The starting point of this analysis is the standard Lerner index for a profit maximizing monopoly. At the profit maximizing level of sales volume, the percentage markup equals the inverse of the own price elasticity of demand, where $\mathrm{P}$ is the retail price, $\mathrm{MC}$ is marginal costs and $\mathrm{E}_{\mathrm{p}}$ is the price elasticity:

$$
\mathrm{L}=(\mathrm{P}-\mathrm{MC}) / \mathrm{P}=-\left(1 / \mathrm{E}_{\mathrm{p}}\right)
$$

In order to calculate the average percentage markup, it is assumed that $\mathrm{MC}$ corresponds to the average wholesale price per bottle imported by Nordpolet at Svalbard. As mentioned before, the wholesale prices are approximated as the before markup and before-tax prices at mainland Norway plus extra transportation costs to Svalbard. A markup of $78 \%$ from marginal cost to the retail price, i.e. P/MC equals 0.78 , corresponds to a markup of $44 \%$ when measured in relation to the retail price $(\mathrm{P})$. The result will be a price elasticity of -2.3 , which appears somewhat higher than expected a priori, although a monopoly will operate on the elastic part of the demand curve.

An empirical study, Flaten and Lilland (2017), finds the own price elasticity of wine demand in Norway to be -1.309 , and -0.928 in the tax-free shops at the Norwegian airports, and these estimates of price elasticity are also applied in Schrøder and Sveinung (2017). A meta-analysis of alcohol price and income elasticities summarizes the price elasticity of wine to be -0.45 , cf. Nelson (2013). The latter value indicates price inelastic wine demand but relates to competitive conditions and therefore it is of less relevance in the present case. A monopoly like 
Nordpolet with some degree of profit maximization will operate on the elastic part of the demand curve, and thus the markup found for Nordpolet corresponds to a fulfillment of this condition. Still, a price elasticity of -2.3 as calculated by using a simple rule like the Lerner index seems to be on the high side. There is less uncertainty on the estimate of the markup of $44 \%$ in relation to the wholesale prices as this is based on the open and full information on the pricing policy at Vinmonopolet. When the most likely value of the price elasticity will be somewhat below -2 (in absolute values), the markup should be higher than $44 \%$ if Nordpolet would follow a full profit-maximizing behavior. Figure 1 is also revealing that wine prices at Nordpolet are lower than the corresponding retail prices at Vinmonopolet. The latter is a (state) monopoly where the price setting is regulated by law in order to influence the consumption from health and social considerations and not for maximizing profits, cf. also Nelson and McNall (2017) for a discussion on these issues. Therefore, Vinmonopolet might be operating above full monopoly pricing and Nordpolet below, but the latter still with higher prices than the tax-free level. Therefore, to answer the hypothesis from Section 3, the tax-free outlet is exercising some degree of monopoly pricing, i.e. extracting a profit from consumers, but acting with a price level below the theoretically optimal monopoly price level. Other considerations might be at work like the many tourists visiting Svalbard each year and with a likely holistic tourist policy in terms of offering a package of goods services at reasonable costs. The surplus from the Nordpolet shop is fully used for various social activities in the local community, which is therefore an incentive to extract a surplus from the tourist consumption of wines. Thus, the pricing of wines at Nordpolet should be seen in a broader perspective.

\section{Concluding Remarks}

The aim of this paper is to contribute to the ongoing discussion of whether tax-free prices are lower than ordinary retail prices outside the tax-free shops. Using wine price data for mainland Norway and for the tax-free island Svalbard, we found that the retail prices are in fact lower on Svalbard. This was expected, but when calculating the wholesale before-tax prices for Norway, they show up to be somewhat below the prices on Svalbard. There is a high degree of correlation between wine prices, but the tax-free Svalbard prices are in no way identical to the Norwegian before-tax prices. Thus, it seems that tax-free shops like Nordpolet might apply a monopoly price setting and thereby extract some surplus or profit from the market. For the Svalbard shop, the estimated markup of $78 \%$ - measured as the retail price in relation to marginal cost - is not fully consistent with pure monopoly behavior as prices seem to be set somewhat below the profit maximizing level. Therefore, the conclusion is that prices in a tax-free shop might be attractive compared to a retail market where the good in question (like wine) is taxed, but also that the tax-free monopoly prices extract a considerable part of the consumer's surplus.

\section{References}

Flaten, C., \& Lilland, A. G. (2017). Forretningsmodell for lufthavnsdrift. Master Thesis, NHH Norwegian School of Economics.

Karlsson, T. (1999). A tax paradise in the making? Alcohol regulations in the Åland Islands. Contemporary Drug Problems, 26, 3-30.

Lai, M. B., Cavicchi, A., Rikertsen, K., Corsi, A. M., \& Casini, L. (2013). Monopoly and wine: the Norwegian case. British Food Journal, 115, 314.326. https://doi.org/10.1108/00070701311302267

Nelson, J. P. (2013). Meta-analysis of alcohol price and income elasticities - with corrections for publication bias. Health Economics Review, 3, 1-17.

Nelson, J. P., \& McNall, A. D. (2017). What happens to drinking when alcohol policy changes? A review of five natural experiments for alcohol taxes, prices, and availability. European Journal of Health Economics, 18, 417-434. https://doi.org/10.1007/s10198-016-0795-0

Nordpolet, Svalbard: https://www.svalbardbutikken.no/no/vareutvalg/nordpolet (Wine prices, Svalbard)

Oslo Economics. (2015). Betydning af konkurrance om å drive duty-free-handel ved norske lufthavner. Report 2015-7. Retrieved from https://osloeconomics.no/

Schrøder, R., \& Sveinung, K. (2017). Vinmonopolet og taxfree-ordningen. Master Thesis, NHH Norwegian School of Economics.

Timothy, D. J., Saarinen, J., \& Viken, A. (2016). Editorial: Tourism issues and international borders in the Nordic region. Scandinavian Journal of Hospitality and Tourism, 16, 1-13.

https://doi.org/10.1080/15022250.2016.1244504

Vinmonopolet, Norway: https://www.vinmonopolet.no/ (Wine prices, mainland Norway) 
Wine Searcher: https://wine-searcher.com (Wine prices)

\section{Copyrights}

Copyright for this article is retained by the author(s), with first publication rights granted to the journal.

This is an open-access article distributed under the terms and conditions of the Creative Commons Attribution license (http://creativecommons.org/licenses/by/4.0/). 